Anat. Labor. of Prof. H. SETO, Tohoku University, Sendai.

\title{
On the Innervation of Glandulae Sublingualis et Sub- mandibularis and their Surroundings in the Earlier Stage of Human Embryo.
}

\section{人胎生初期に於ける舌下腺，顎下腺及び其周辺の神経分妳に就て。}

Teruo TAKAHASHI 简橋焯 男。

(Received January 15, 1956.)

Histological studies on the innervation of the salivary glands were formerly undertaken by many histologists including PFLÜGER (1869), RETZIUS (1888), CAJAL (1889), KOROLKOW (1892), ARNSTEIN (1893), KÖLLIK ER (1902), ELLENBERGER (1911), STORMONT (1926), OKAMURA (1930), SASYBIN (1933), and ROSSI a. MOCCHI (1935), but the vegetative nerve terminations were represented by them as mere free endings or very coarse-meshed nervous reticules, but, upon collating these with the terminations of vegetative nerve fibres found by means of the modern silver impregnation method - the STÖHR's terminal reticula the difference is indeed surprising. We see that the majority of the terminations described in the reports of the above mentioned predecessors are hardly anything but artefacts created during the very difficult process of nerve staining.

The problem, however, was brought to light at last in 1934 by the study of BOEKE based on preparations stained with BIELSCHOWSKY's method, which was succeeded by the study by SETO and FUKUYAMA (1936) of this laboratory on the innervation of the salivary glands of hedgehog, wherein they used the excellent silver impregnation method perfected by SETO and arrived at many new and highly estimable findings to complement the current informations on the subject. More recently, not only salivary glands, but also many other exocrine glands have been subjected to researches for their innervation, and it has been set beyond doubt that here too, the vegetative nerve fibres always end in terminal reticula, though some difference in the opinions certainly exists as yet on the formation of the reticules. This difference is, I believe, due to the fact that the staining methods used by the different researchers have not yet reached the stage of flawless perfectness. Studies on the vegetative nerve cells, especially of the sympathicus, have also been furthered greatly by the efforts of STÖHR and his successors, and many and great have been the results obtained, but we must say that such studies from the embryological angle have been only very few and far between. 
So, the author of this paper was led to attempt an embryological study on the innervation of the glandula sublingualis, the glandula submandibularis, the bottom of the oral cavity, and also of the ganglion submandibulare, and make some contributions in supplementing the meagre current informations on the subject. As my subjects, I took human embryos of $3-4$ months, and taking samples of the oral cavity bottom including the lower jaw fixed for long time in $10 \%$ neutral formol from them, cut them into $40 \mu$ frozen sagittal sections. These were stained with the ideal SETO's silver impregnation method and subjecting the large series of beautiful tissue preparations to a thorough microscopic examination, I succeeded in arriving at the results reported in the following.

\section{Individual Observations.}

It is needless to reiterate that the sublingual gland in a human embryo of only 3-4 months is much simpler in structure than that in a human adult, and yet, it is then already represented therein as a simple branched gland duct system arranged loosely in a connective tissue rich in fibrocytes (Fig. 1). The formation of the connective tissue capsule around the lobuli, however, is as yet not sufticiently distinct. The alveoli are indicated by single rows of infantile gland cells, of which the bodies are almost entirely taken up by solitary large-sized cell nuclei, showing a yet very low stadium of differentiation in most cases, but in a very small number, some alveolar cells already mucified have been found. The major ducts, such as the ductus sublingularis of the gl. sublingualis major and the ductus sublinguales minores have comparatively large lumina and are lined by a double-rowed cubic or cylindrical epithelium, but the small ones are lined by a single-rowed epithelium. This gland is very rich in blood vessels and nerve fibres.

Closely adjacent to the dorsocaudal side of the gl. sublingualis is found the gl. submandibularis. Here it must be noted that the very large ganglion submandibulare is formed between these two glands, partly jutting into their interspace (Fig. 2). The submandibular gland also is represented as a simple branched gland duct system spread out in a richly celled loose connective tissue, as the preceding.

The ductus submandibularis is lined by a double-rowed cylindrical epithelium rising in height oralwards and has a rather wide lumen. The n. lingualis is seen running along this duct. The epithelial cells forming the alveoli of this gland also are in a very low differentiation, showing little in form that distinguishes a gland cell. The intercalated and the secretory ducts are as little differentiated, have considerably wide lumina and are lined by a single-rowed cubic epithelium. The submandibular 


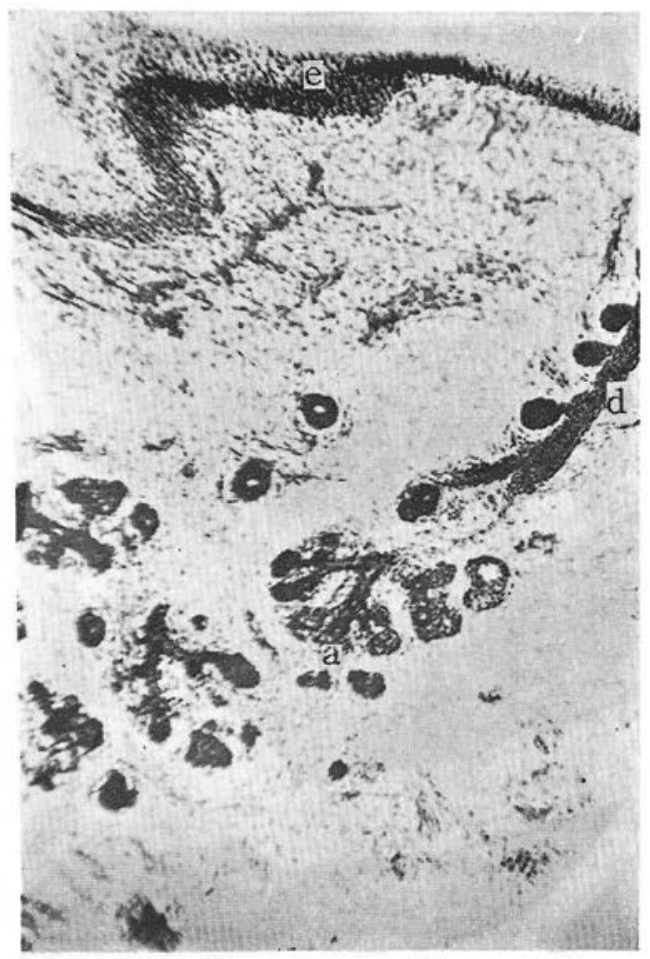

Fig. 1. Gl. sublingualis of a 4 th month human embryo. Sagittal section. $a$ alveolus, $d$ gland duct, $e$ epithelium of the bottom of oral cavity. Details in the text. SETO's impregnation. Photo $\times 70$.

gland is very well provided with blood vessels and nerves, but as in the gl. sublingualis above, its lobuli and the connective tissue capsule surrounding them are as yet very low in development. It has been demonstrated by MIKAMI in his study on the spinal ganglia that the nerve tissue shows an incomparably prompter development than all the outer tissues in the early stage of embryonic life, and this has been observer very clearly in the ganglion submandibulare of a human embryo of 3 or 4 months. In fact, this ganglion was much larger than the other tissues in size and the nerve cells in it were in a stage of considerably high differentiation.

This large ganglion mandibulare contains some nerve bundles run. ning horizontally oralwards with very numerous nerve cells in it and takes in the sympathetic roots coming from the dorsal side from the sympathetic trunk in the neck. Closely above this ganglion runs a large 


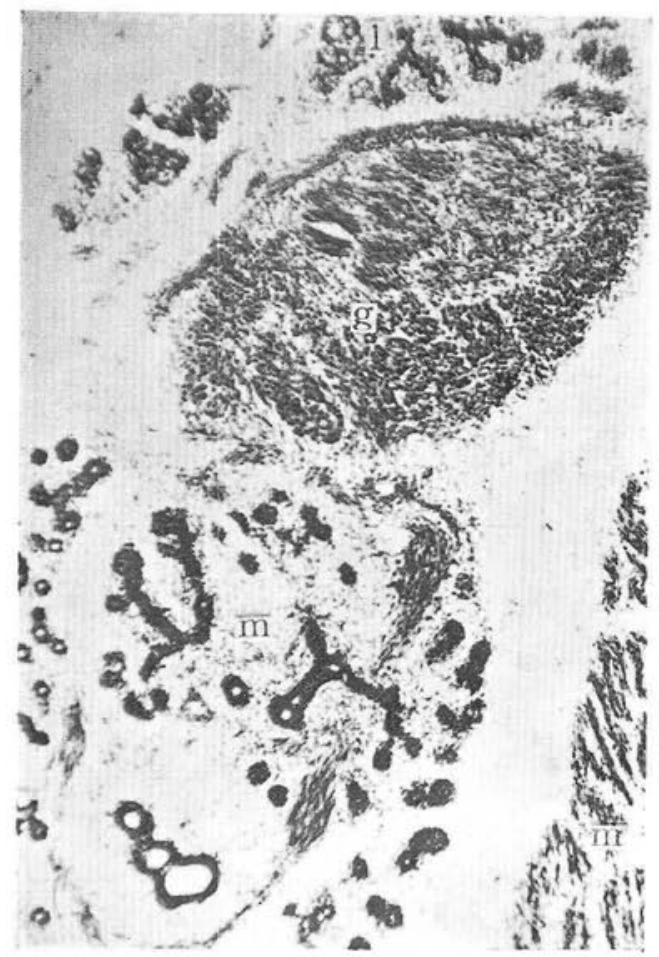

Fig. 2. Ganglion submandibulare $(g)$, gl. submandibularis $(m)$ and gl. sublingualis $(l)$ of a 4 th month human embryo. Sagittal section. $n$ comparatively thick nerve bundle penetrating into the parenchyma of $\mathrm{gl}$. submandibularis, $m^{\prime}$ striated muscle. Details in the text. Same staining.

\section{Photo $\times 50$.}

nerve bundle of the $\mathrm{n}$. lingualis forewards and a very close relation between the two is assumed, for some nerve cell groups are found migrated into the nerve bundle, especially in its lower part. It is of interest that this ganglion is seen extending to a considerable distance forward along the underside of the gl. sublingualis. This extension seems to be identical with the ganglion sublinguale shown in all illustration in BAUBER-KOPSCH's text book, but it seems necessary to wait for the results of future studies for deciding whether this formation remains intact in human adults. Besides, nerve bundles of various sizes are sent out from the underside of the ganglion submandibulare into the parenchyma of the gl. submandibularis. Nerve branches from the ganglion are seen runnnig into the gl. sublingualis also in a large quantity. 
The nerve cells in the human ganglion submandibulare have their outline as multi-polar cells well formed in the $3 \mathrm{rd}$ or 4 th month of embryonic life already. Of course, in the $41 \mathrm{~h}$ month, the cells are a little higher in differentiation than in the 3rd month. As shown in Figs. 3

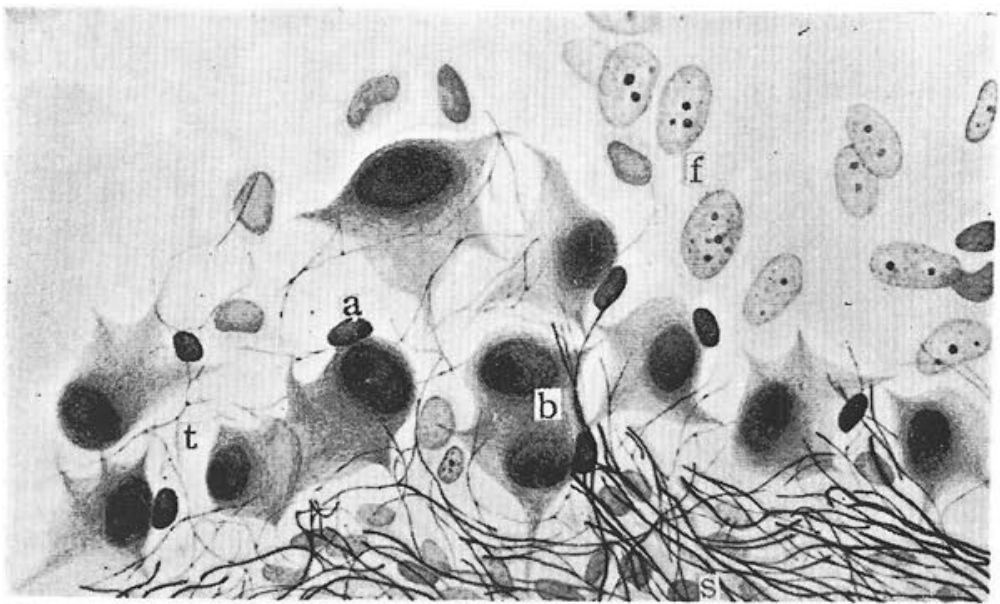

Fig. 3. Nerve cells situated in the periphery of the ganglion submandibulare of a 4 th month human embryo. Sagittal section. $b$ binucreated nerve cell, $a$ nucleus of accessory cell plasmodium, $s$ SCHWANN's nuclei in the nerve fibres, $t$ pericellular terminal reticulum, $f$ fibrocytes. Details in the text. Same staining. $\times 400$.

and 4 , the nerve cells are mostly mononuclear, but rarely some binuclear ones are also found. They are stellar in shape and have $3-5$ nerve processes each. Extremely minute neuro-fibrillar nets are seen formed in their bodies. These nets pass over into the processes one by one. The cell nuclei are in most cases spherical or ellipsoid and considerably large, occupying about one third or sometimes even half of the whole bulk of the cell bodies, and are rich in chromatin. The nucleolus in the nucleus is not yet distinguishable at this stage. Quite as in adults, the nucleus is placed at the center of the cell body rather rarely, in many more the position being eccentric, and marginally standing nuclei are not rare at all.

The short processes from these nerve cells are very short indeed and end very simply in sharp points without showing complex branching, as in human adults. The long processes usually merge one each per cell, but sometimes a cell is found sending out two of them. The accessory cellplasmadium around the nerve cell (STÖHR) is very ill developed, accessory cells around one nerve cell being only a rare occur rence and the usual arrangement being one solitary accessory cell per nerve cell. A 


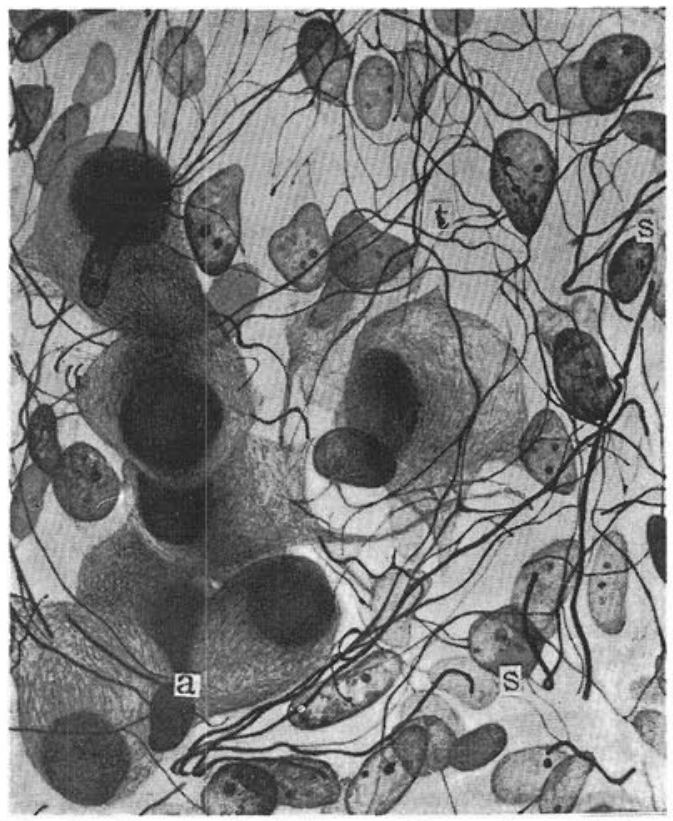

Fig. 4. Nerve cells in the ganglion submandibulare of a 4 th month human embryo. a nucleus of accessory cell plasmodium, $s$ SCHWANN's nuclei in the pericellular terminal reticulum $(t)$. Details in the text. Same staining. $\times 400$.

similar paucity of the accessory cells was also observed in the spinal ganglia of early embryos (MIKAMI). In the spinal ganglia, however, the number of the special nuclei was found to be somewhat larger than in my ganglion submandibulare. Now, as is well known, such accessory cell nuclei are rather numerous in human abults, in particular, around the nerve cells sending out many short processes that branch out in a complex manner. For example, amidst the many nerve processes emering from the process ples of a jelly-fish or octopus type cells (SATO) these are found crowded in groups. From this observation, we may presume that these special nuclei are proliferated in proportion to the differentiation and development of the nerve processes, especially, the short processes. The development of the connective tissue capsule encasing the accessory cell plasmodium is also very poor in the early embryonic life, no connective tissue cell being commonly found at all.

The nerve fibres of the nerve bundles running through the ganglion submandibulare are already in obvious formation in this stage of embryonic life. Nervous anastomosis is sometimes seen between the running fibres. The SCHWANN's nuclei found around the nerve fibres are also 
notably developed. They are found in a considerable number dispersed along the nerve fibres, are mostly club-shaped and contain chromatin arranged much more loosely than in the nuclei of the nerve cells.

The nerve fibres coming into the ganglia, as seen in Fig. 3 and more clearly in Fig. 4, gradually taper off while undergoing ramification and mutual anastomosis and developing into the common pericellular terminal reticulum covering many nerve cells spread out over a large area. Such a terminal reticulum is formed into an irregular net work of finest fibres which undergo very frequent changes in their size. It is extremely difficult to make out whether such a reticulum comes into direct contact with the nerve cells, but the result of my painstaking investigation seems to deny such a direct contact. Thus, the termination of the incoming nerve fibres formed around the nerve cells in the sympathetic ganglia is somewhat different morphologically from the regularly arranged neurofibrillar terminal reticulum supplied to the smooth muscle fibres and the gland cells, as detailed below.

Nerve bundles of various size are sent out into the gl. submandibularis from the ganglion submandibulare. Nerve branches are also sent into the gl. sublingualis from the ganglion or the ganglion sublinguale. These nerve branches consist of sheer fine fibres, most of which may be of sympathetic nature, but some among them must belong to the parasympathicus. These parasympathetic fibres originate in the chorda tympani coming out of the $\mathrm{n}$. intermedius. Many researchers have opined that a part of the parasympathetic fibres contained in the n. glossopharyngeus run through the $n$. tympanicus and the ganglion oticum and further through the $\mathrm{n}$. lingualis into the ganglion submandibulare, reaching thence finally into the two glands. In this manner, the vegetative elements supplied to these glands consist in sympathetic and parasympathetic fibres, but both of the kinds of fibres being very fine in this peripheral part, the microscopic distinction of the two is almost impossible. In these two glands, beside the above nerve fibres, the so-called periarterial plexus formed of vegetative fibres along the blood vessels, especially, the arteries, are found very well developed in the $3 \mathrm{rd}$ or 4 th embryonic month. Small ganglia are also often found in the nerve bundles running into the parenchyma, and rather thick sensory fibres originating in the $\mathrm{n}$. lingualis of sensory nature are seen mingled with the vegetative nerve fibres.

The vegetative nerve fibres distributed in the gll. sublingualis and submandibularis are terminated in the STÖHR's terminal reticulum, as in all the other parts of the body. Here, the terminal reticula are represented by finest nerve nets extending cordwise and composed of finest fibres attenuated beyond further division, and their mesh-work is very 
fine and formed with considerable regularity. The joints of these fibrils are often formed into small knobs. These reticula are never ended freely, but always are subject to anastomosis with each other. Thus, the vegetative fibres form a single grand net-work. The nerve cords making the terminal reticula range from considerably large to very small ones in size and the net formation at the parts of decussating conjunction of 2 or 3 of such cords is very extensive. I have stated in the above that chromatin-poor club-shaped SCHWANN's cell nuclei are found along the nerve fibres. These nuclei are found also in the parts where the nerve fibres begin to spread out into the terminal reticula, that is, along the REISER's praeterminal fibres, and some are also found scattered in the terminl reticula adjoining them.

These terminal reticula, as shown in Figs. 5 and 6 , are in marked

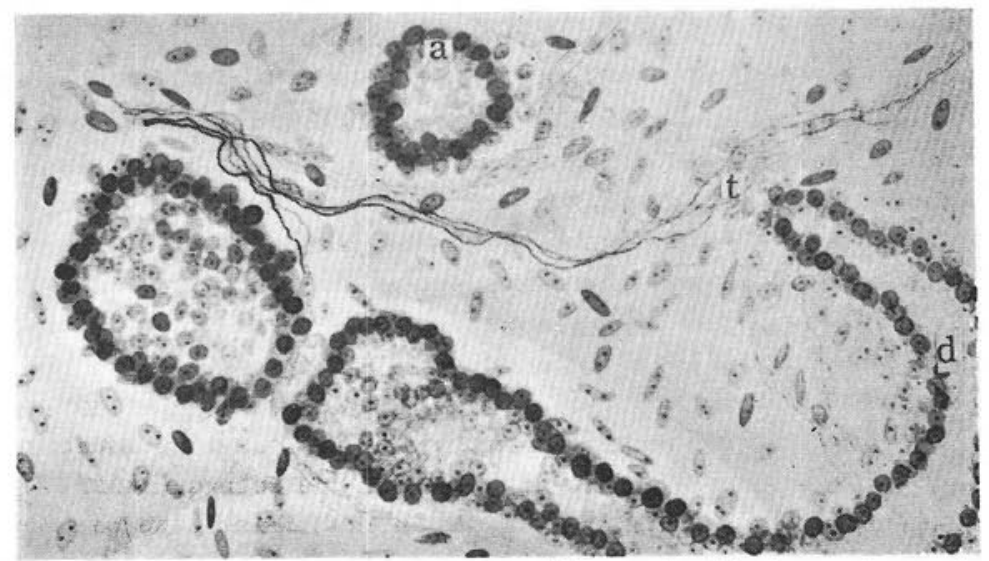

Fig. 5. Vegetative terminal reticulum $(t)$ in marked development around the alveolus $(a)$ and the small duct $(d)$ of the gl. sublingualis of a 4 th month human embryo. $p$ praeterminal fibres. Same staining. $\times 400$, reduced to $5 / 6$.

development in the parenchyma, particularly, around the alveoli, and are formed around the small gland ducts and the large ducts of the two glands, too. When observed more closely, it is certain that these reticula are densely arranged around the gland cells of the alveoli and the epithelial cells of the gland ducts, but I failed to observe any figure of their side branches running into the cell bodies - a point still in controversy among the European researchers. Thus, I cannot accept the theory postulating the existence of such side branches. Certainly, I frequentlv met with nerve cords running a course as if penetrating through the epithelial cells, but upon closer examination, I could confirm that they never pass through the cell bodies in reality. 


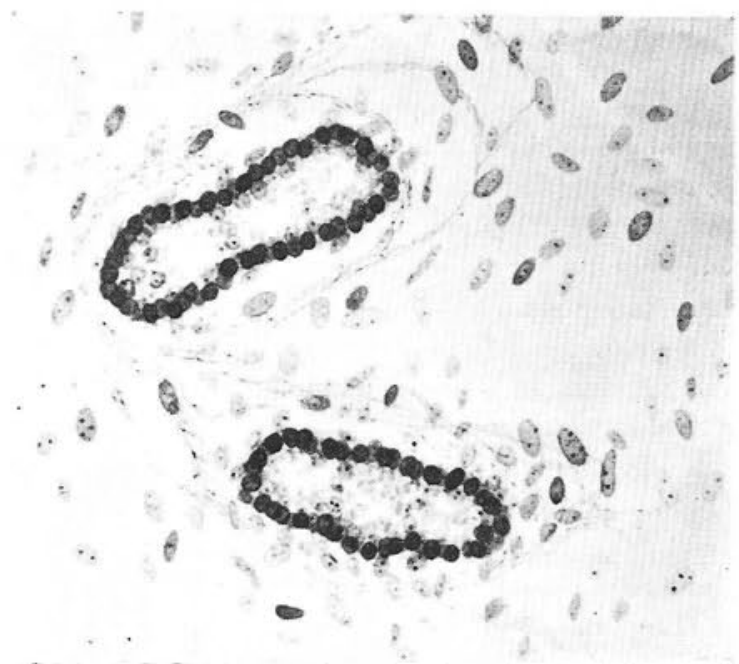

Fig. 6. Terminal reticulum distributed a round the small ducts of the gl. submandibularis of a $4 \mathrm{th}$ month human embryo. Same staining. $\times 400$.

The periarterial plexus running alongside the blood vessels, especially, the small arteries, come into anastomosis frequently amidst the above mentioned secretory nerves through their side branches. Typical terminal reticula are formed in the arterial walls also, where they stand in control over the smooth muscle fibres by contacting and surrounding them.

A part of the vegetative fibres coming into the sublingual gland run further into the submucosa and the propria of the mucous membrane of the bottom of the oral cavity and spread out into the terminal reticula in the connective tissue in this part. These reticula, however, are much worse developed than those in the gl. lingualis.

The sensory fibres originating in the $\mathrm{n}$. lingualis are much thicker than the above vegetative fibres, so that they are very easily distinguished histologically from the latter, but as the myelin sheaths are not yet formed around them, some care is required in preventing confusion. The vegetative fibres, however, usually show mutual anastomosis at frequent intervals in their courses, while the sensory fibres run sometimes in company with vegetative fibres but as often separately, and such distinguishing facts may also come in to help the histological distinction.

Some of the sensory fibres coming out from the n. sublingualis run through the parenchyma of this gland and the others outside of it, but anyhow they come into the mucous membrane of the oral cavity bottom to end mostly close to the stratified flat epithelium there. In their courses, however, they often form terminations around the ductus submandibularis, 
the ductus sublingualis and the ductus sublinguales minores, in particular, in the vicinty of their outer openings.

Now, accrding to the studies by OHGAKI and HOTTA of this laboratory, in the oral cavity base of human adults, papillae from the propria protruding into the epithelium and more rarely, taste buds are found formed but yet the sensory innervation is nothing good there, that is, the number of sensory fibres reaching this part is limited and their terminations are rather simple in construction in human adults.

Since in my specimens from 3-4 months embryos, the papilla formation into the epithelium, not to speak of the taste buds, is nearly nil, it is easy to surmise that the sensory fibres here would be terminated very simply. In fact, the sensory terminations in this part in the early stage of embryonic life are found to be nothing but of unbranched or simple branched type, any such complex structures as found often in adults being entirely absent. On some rare occasions, however, I could find terminal fibres running coures of somewhat higher complexity, such as very peculiar ansiform courses or courses accompanied by change in size peculiar to sensory fibres. The terminal fibres in terminations of any kind end in sharp ponts with scarcely any exception. No sensory fibre here was found to run further up into the epithelium of the gland ducts or the stratified epithelium of the bottom of the oral cavity to form intraepithelial fibre, as was the case with human adults (OHGAKI and HOTTA).

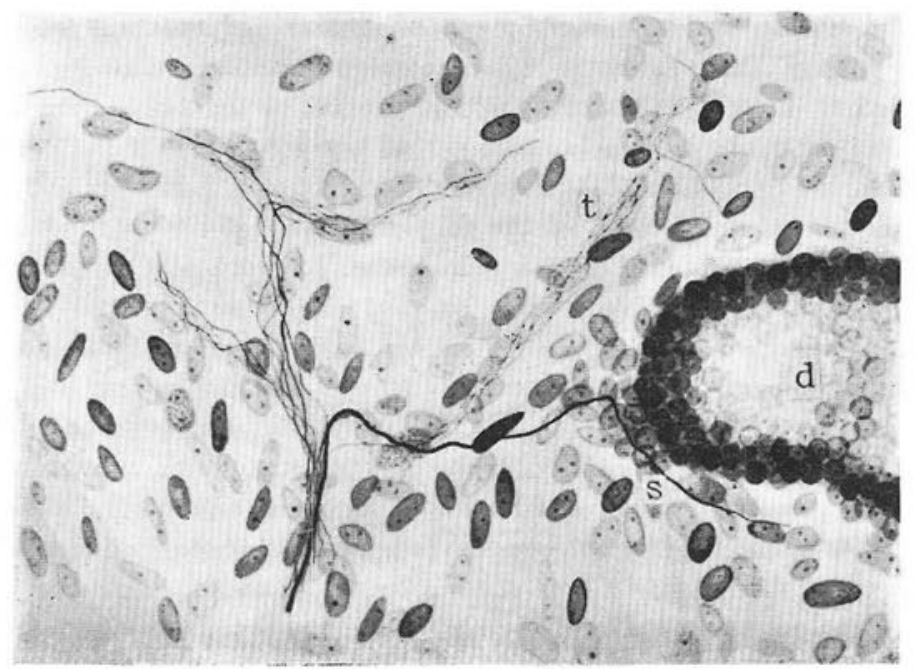

Fig. 7. Distribution of vegetative nerve fibres and an unbranched sensory termination $(s)$ around the ductus submandibularis $(d)$. $t$ terminal reticulum. Details in the text. Same staining. $\times 400$. 
An unbranched sensory termination formed along the ductus submandibularis and ending sharply is shown in Fig. 7. The stem fibre of this termination runs a common course with some vegetative fibres. Fig. 8

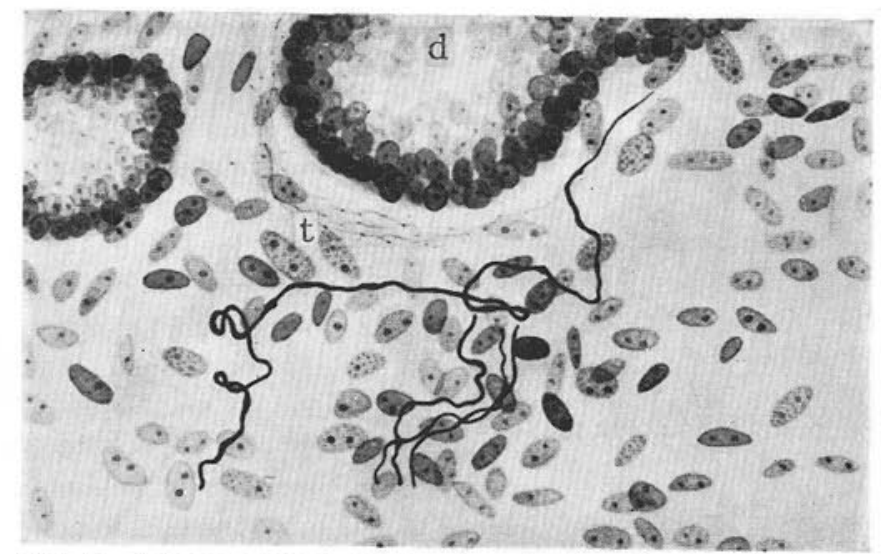

Fig. 8. An unbranched sensory termination showing thrice repeated ansiform circling found around the ductus sublingualis minor $(d)$ of a 4 th month human embryo. $t$ terminal reticulum. Details in the text. Same staining. $\times 400$.

shows another unbranched termination in the vicinity of a ductus sublinguaris minor showing a peculiar winding course. A considerably thick solitary sensory stem fibre, before reaching the close vicinity of the duct and ending sharply, makes thrice repeated ansiform circling in the terminal area. This fibre shows frequent change in size. In Fig. 9, we see

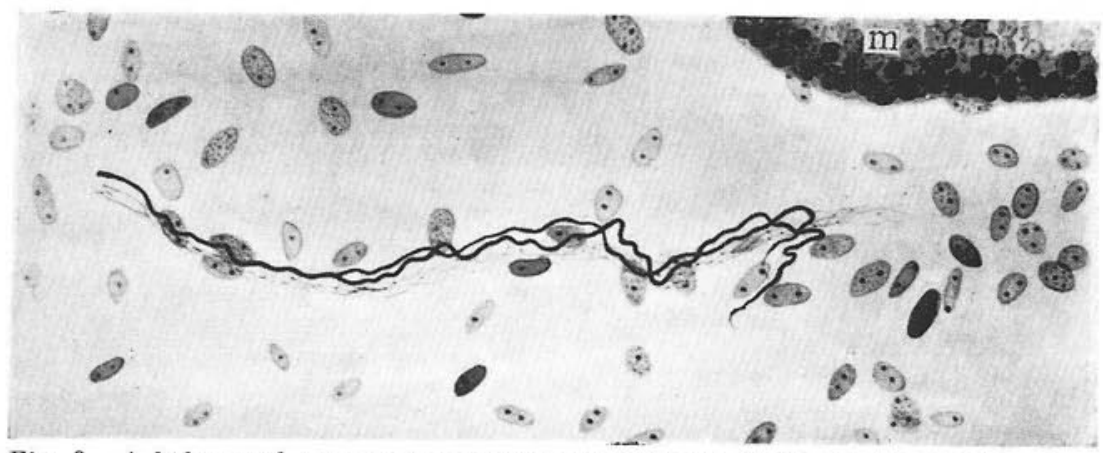

Fig. 9. A bifurcated sensory termination accompanied by the fine vegetative terminal reticulum found around the ductus submandibularis $(m)$ of a 4 th month human embryo. Details in the text. Same staining. $\times 400$.

a simple branched termination, of which, the stem fibre bifurcates into two branches which both run rather long wavy courses and then end in 


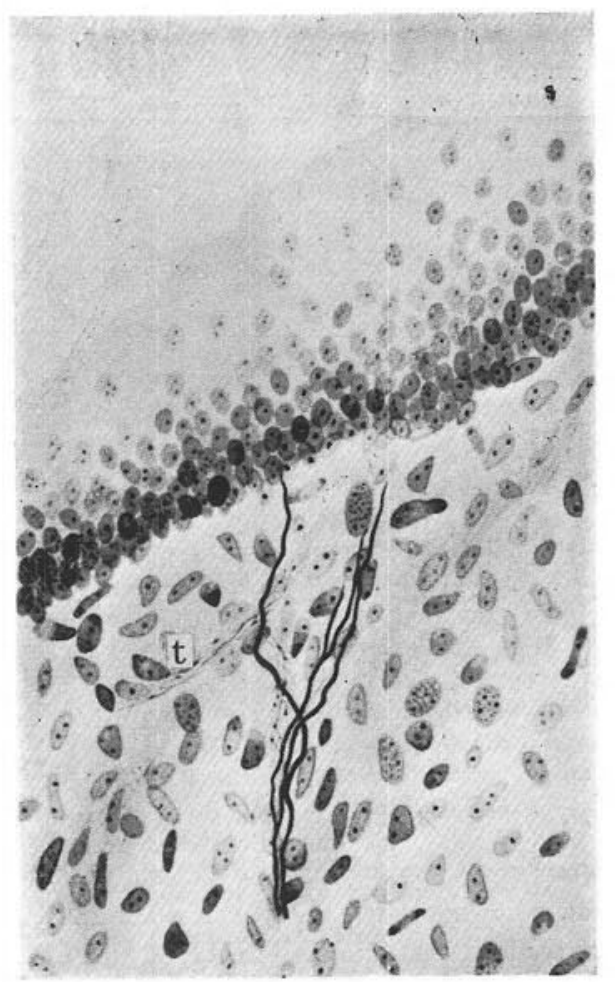

sharp points. Fine vegetative fibres, which finally form a cord-like terminal reticulum, is seen running in company with this sensory fibre.

In Fig. 10, 11 and 12 are shown unbranched and simple branched terminations formed in the propria consisting of a connective tissue rich in cells beneath the epithelium lining the bottom of the oral cavity. In Fig. 10, we see two sensory fibres running abreast,

Fig. 10. An unbranched and a simple branched sensory terminations formed in the propria of the bottom of the oral cavity of a 4 th month human embryo. Sagittal section. Details in the text. $t$ terminal reticulum. Same staining. $\times 320$.

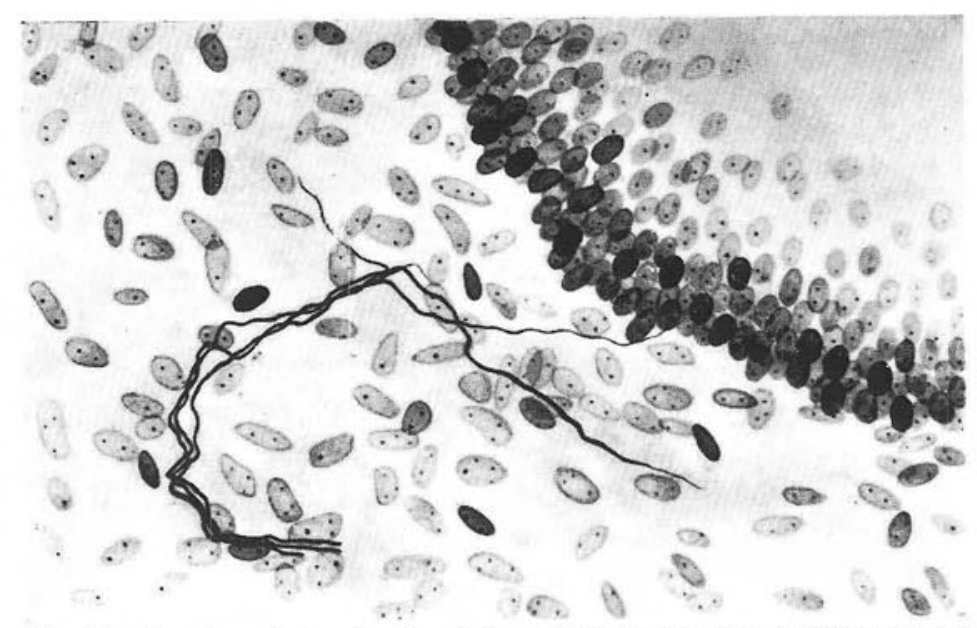

Fig. 11. 2 unbranched and a simple branched sensory terminations formed subepithelially. Oral cavity bottom of a 4th month human embryo. Sagittal section. Details in the text. Same staining. $\times 400$. 
of which one ends unbranched and the other in a simple branched termination composed of three branches. These terminal fibres and branches all run rather straight courses perpendicular toward the epithelium to end sharply. The weakly formed terminal reticulum is seen running along these fibres. In Fig. 11 are found 3 unbranched and one simple bifurcated terminations, of which the terminal branches diffuse parallel to the epithelial basis subepithelially. Fig. 12 shows an unbranched and

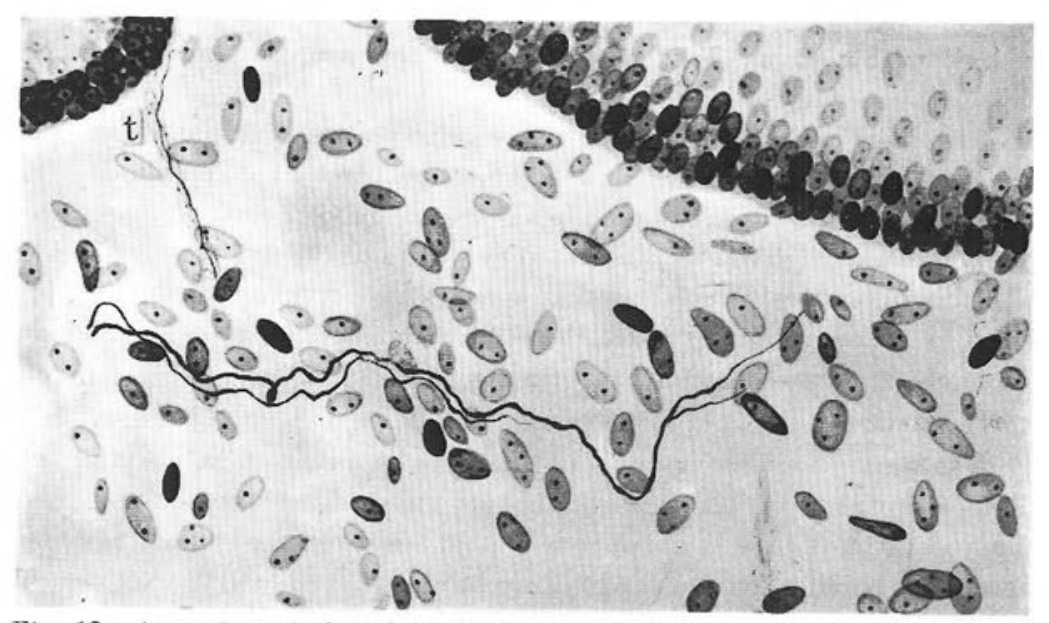

Fig. 12. An unbranched and a simple branched sensory terminations found subepithelially. Oral cavity bottom of a 4 th month human embryo. Sagittal section. $t$ terminal reticulum. Details in the text. Same staining. $\times 400$.

a bifurcated terminations, of which the fibres run similarly in parallel to the epithelium but in wavy courses, within the propria and end in sharp points. The terminal fibres show occasional change in size in their terminal areas.

\section{Summary.}

The gl. sublingualis and the gl. submandibularis in a human embryo of 3 or 4 months are found as simple branched duct systems sporadically arranged in the loose connective tissue, and their alveoli are formed by undifferentiated gland cells arranged in one row. In the gl. sublingualis, however, some mucosal cells are already formed. The large ducts of these glands are lined by a double-rowd cubic or cylindrical epithelium, but the intercalated and the secretory ducts of the submandibular gland are not yet differentiated and are lined by a single-rowed cubic epithelium. These glands are abundantly provided with blood vessels and nerves.

The ganglion submandibulare is extremely well developed and stretching toward the sublingual gland, forms the so-called ganglion sublin- 
guale. Small ganglia are also found migrated into many places in the $\mathrm{n}$. lingualis. More or less thick nerve bundles are found running out of these ganglia into the submandibular and the sublingual glands, and small ganglia are frequently found in these bundles too.

The nerve cells in the ganglia are already in a considerably high development. They are in the form of multipolar cells with $3-5$ nerve processes and contain each one or sometimes two large nuclei, which are usually eccentric or marginal-standing and show as yet no formation of nucleoli within them. Fine nerve fibrillar nets are contained in the cell bodies.

The short processes from the nerve cells are not yet in the stage of ramification, but running only a short course, and in sharp points. One or sometimes two long nerve processes are sent out per cell. The accessory cell plasmodium (STÖHR) is as yet very poorly developed, being provided with one or two cell nuclei around a nerve cell. These nuclei are presumed to increse in number with the differentiation of the short processes. The connective tissue capsule covering such a plasmodium is also still very poorly developed.

The nerve bundles running in the ganglia submandibulare and sublinguale are already very conspicuously formed. These always consist of fine vegetative fibres, which show mutual nervous anastomosis here and there. The bundles contain chromatin-poor club-shaped SCHWANN's nuclei rather frequently.

The external vegetative fibres coming into the ganglia also undergo frequent anastomosis and gradually losing in size, develop finally into the pericellular terminal reticulum common to a number of nerve cells. This reticulum is formed of fine nerve fibrils showing frequent change in size and forming an irregular mesh-work. No direct connection seems to exist between the reticulum and the nerve cells.

The fibres in the numerous bundles running into the two glands comprise both sympathetic and parasympathetic fibres, but it is impossible to distinguish between the two kinds. The development of the vegetative periarterial plexus formed around the arteries is already much advanced. This plexus here and there anastomosis with the vegetative nerve bundles mentioned above.

The termination of the vegetative fibres distributed in the salivary glands is also represented by the STÖHR's terminal reticulum formed of finest fibrills and extending cordwise. The mesh-work of the reticulum in the glands is finer and more regular than that of the pericellular terminal reticulum above. SCHWANN's nuclei are frequently found in this reticulum too. The terminal reticulum is in particularly good formation around the alveoli and the ducts of the glands and diffuses closely 
in contact of the epithelial cells, but apparently never send out side branches into their cell bodies. The terminal reticulum stands in tactile control over the smooth muscle fibres in the arterial walls, and is frequently found in the mucous membrane of the bottom of the oral cavity too.

The sensory fibres originating in the $\mathrm{n}$. lingualis, though as yet unprovided with myelin sheaths, are much thicker than the vegetative fibres. These usually run through or along the sublingual gland and attaining the mucous membrane of the bottom of the oral cavity end subepithelially there, but it is not rare that some of the fibres make terminations around the large gland ducts before going thus far.

In the early stage of the embryonic life, little or no formation of papillae from the propria into the epithelium and of taste-buds is found in the bottom of the oral cavity. Consequently, the number of sensory fibres here is small and their terminations are also extremely simple, nothing more complex than unbranched and simple branched types being found here. No such a complex termination as found by OHGAKI and HOTTA in adult human mouths never to be found developed. Some terminal fibres, however, were found to run peculiar ansiform courses or to show changes in size peculiar to sensory fibres. The terminal fibres in all cases usually end in sharp points. No intraepithelial fibre ending in the epithelium of the gland ducts or the bottom of the oral cavity could be found.

\section{内容自抄。}

人 3-4ケ月胎䅐の舌下腺及䫛下腺は甚だ単純な分岐性管系で表わされ， 腺末端部の細胞は末分化の状態を示す。但し舌下腺では小量の粘液性細胞 の出現を完る．之等腺の大導管は二列性細胞から成るが，潤管も分泌管も 未分化状態を示し 1 列性立方細胞から成る.

枵下神経節は既飞強力飞発達し舌下腺の方飞まで伸びて所謂舌下神経節 飞移行する. 又小神経節は舌神経の所々飞迷入する. 以上の神経節から顎 下腺及び舌下腺内飞伸びる神経束の中方小神経節の形成を芫る，神経細 胞は比較的高度飞発達し，3-50神経突起を有し，中に1つ特には2つの 大核を有す。此核は概ね中心外飞めり，核小体の形成は末だ兒られない。 細胞内には既湟線維網が証明される。

神経細胞からの短突起林旧分岐性で尖鋭状に終る。長突起は 1 細胞 に 1 条時には 2 条発芫される。副細胞 plasmodium 溌達甚だ劣勢, 細胞 周囲に 1-2 核を有するに過ぎない。此核は短突起の分化飞伴い增殖する るのであろ 5 . 又 plasmodium 外の結合織囊も発達劣勢である. 


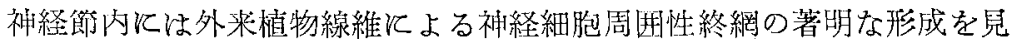
る。此終網は所々に太さの変化を示す微細線維の不規則な配列で表わされ， 神経細胞に対する直接的結合走示さない。

顎下腺不び舌下腺に対する神経線維の交感及び副交感性の組織学的判別 は不可能である，血管周四神経丵も既に発達良好，他の植物線維と各所で 神経㽖合を行う。

両唾液腺に拡散する植物線維も遂には終網（Stöhr）に移行する，之は 神経細胞凰用性終網に於けるより遥か飞微細な線維の規則正しい配列で構 成され，中飞 Schwann 氏核を含吉，終網活腺末端部や導管の周り飞強力 に形成される，然し細胞体の中までは入らない，又血管壁でも発達良好，

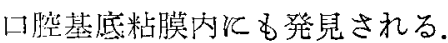

舌神経からの知党線維は未だ髓鞘を伴わないが，椬物線維よりは遥が 太く，舌下腺の内外を通って，多くは口腔基底粘膜の上皮下に終る．然し 経過途上大きな導管の周囲に終る事も稀でない。

人胎生初期の口腔基底で浮烰や昧䈏の形成は未だ見られない，従って ここには知覚線維の量も少く，其終末も甚だ単繥，非分岐性及び単純性分 岐性終末で柿わされるに過ぎず，成人に兒られる複雑な終末（大垣と堀田） の如きは末だ何処にも形成されない，但し係蹄状走行又は太さの変化を示 す終末枝の存在懦々発見される。尚招導管や口湟基底の上皮内にも上皮 内線維は挀明されない。

\section{References.}

Arnstein : Anat. Anz. 10 (1895), - Boeke: Z. mikr.-anat. Forsch. 7 (1926), 33 (1933), 34 (1933), 35 (1934). - Acta anat. 8 (1949). - Acta neuroveget. 22 (1951). - Cajal : A rch. Psych. u. Nervenhk. 102 (1934), - Ellenberger: Handbuch der vergleich. mikrosk. Anatomio der Haustiere. Bd. 2. Berlin, P. Parey, 1911. - Freving: Acta neuroveget. 3 (1951), - Hayashi : J. orient. Med. 27 (1937). - Hermann: Virchows Arch. 322 (1952). - Jabonero: Acta neuroveget. Suppl. 4 (1953). - Korolkow: Anat. Anz. 7 (1892). - Mikami : Tohoku J. exp. Med. 58 (1953). - Ohgaki a. Hotta : Tohoku J. exp. Med. 57 (1953). - Okamura : Z. Anat. 91 (1930). -- Pflüger; Arch. mikr. Anat. 5 (1869). - Rauber-Kopsch: Lehrbuch und Atlas der Anatomie des Menschen. Bd. 3. Leipzig, G. Thieme, 1940. - Reiser: Z. Zellforsch. 22 (1935). - Arch. Augenhk. 109 (1936). - Acta neuroveget. 4 (1952), - Retzius : Biol. Unters. N. F. 3 (1892). - Rossi u. Mocchi : Z. Zellforsch. 22 (1934-35). - Sasybin: Z. Zellforsch. 19 (1933). - Sato, H.: Tohoku J. exp. Med. 59 (1953). - Sato, M. : Arch. hist. jap. 8 (1955). - Seto : Arb. Anat. Inst. Sendai. 19 (1936). - Seto a. Fukuyama : J. orient. Med. 25 (1936). - Seto, Yama- 
moto a. Fujii: Tohoku J. exp. Med. 54 (1950). - Stöhr: Mikroskopische Anatomie des vegetativen Nervensystems. Berlin, J. Springer, 1928 - Z. Zellforsch. 27 (1937), 29 (1939), - Lehrbuch der Histologie und der mikroskopischen Anatomie des Menschen. Berlin, Göttingen u. Heidelberg, 1951. - Erg. Anat. 34 (1952). - Stormont: Anat. Rec. 32 (1926). - Toyota : Arch. hist. jap. 7 (1955). - Yamashita : J. orient. Med. 30 (1939). 